Martin G. Ruf

\title{
Die heiligen Propheten, eure Apostel und ich
}

\author{
Metatextuelle Studien zum zweiten Petrusbrief
}

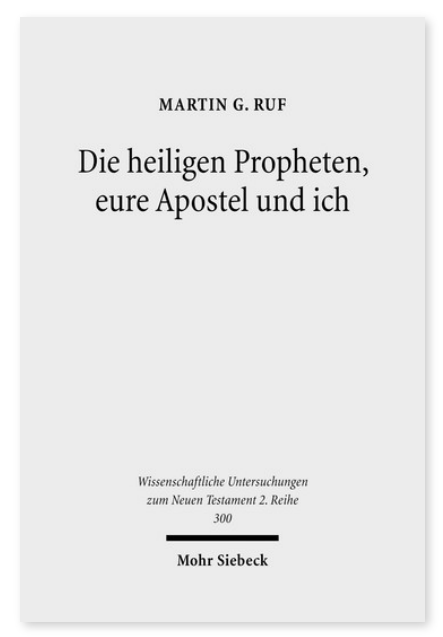

2011. XVII, 688 Seiten. WUNT II 300

ISBN 978-3-16-151643-6

DOI 10.1628/978-3-16-151643-6

eBook PDF 129,00€

ISBN 978-3-16-150592-8

fadengeheftete Broschur 129,00€
Die Zeit, in der Exegeten über das angeblich unbeholfene, literaturferne Griechisch des zweiten Petrusbriefes die Nase rümpften, ist vorbei. Die jüngere Forschung hat dessen Orientierung an literarischen Vorbildern offen gelegt. Eine besondere Gruppe innerhalb des textuellen Universums des zweiten Petrusbriefes stellen dabei die für ihn autoritativen jüdischen und frühchristlichen Schriften dar, auf die er in unterschiedlicher Weise Bezug nimmt. Eine Untersuchung auf der Basis der intertextualitätstheoretischen Erkenntnis, dass Anspielungen, Zitate und andere Formen der Kontaktaufnahme zwischen Texten von der Selbsteinschätzung des verweisenden Textes zeugen, führt zu der Erkenntnis, dass der zweite Petrusbrief seine eigene Position bestimmt zwischen der Funktion von Auxiliarliteratur, die auf die autoritativen Schriften verweist, und dem Anspruch auf Eingliederung in diese Schriftengruppe.

Martin G. Ruf Geboren 1967; Studium (ev. Theologie, Latein, bibl. Hebräisch, Französisch) in Heidelberg, Marburg/Lahn und Halle/Saale; Lehrer für ev. Religionslehre, Latein und Französisch in Schönebeck/Elbe; Assistent in Opleiding Universität Utrecht; derzeit Junior Universitair Docent an der Universität Utrecht; 2010 Promotion.

Jetzt bestellen:

https://mohrsiebeck.com/buch/die-heiligen-propheten-eure-apostel-und-ich-9783161516436?no_cache=1 order@mohrsiebeck.com

Telefon: +49 (0)7071-923-17

Telefax: $+49(0) 7071-51104$ 